\title{
fIIISGUC.ORG
}

"İȘ, GÜC̣" ENDÜSTRi iLIȘKiLERi VE INSSAN KAYNAKLARI DERGISi

"IS, GUC" INDUSTRIAL RELATIONS AND HUMAN RESOURCES JOURNAL

\section{Beyaz Yakalıların Tanımlanması Üzerine}

\author{
On The Definition Of White Collar Workers
}

\section{A. Utku ERDAYI}

Araş.Gör.Dr., Marmara Üniversitesi, İktisadi ve İdari Bilimler Fakültesi, Çalışma

Ekonomisi ve Endüstri İlişkileri Bölümü

Temmuz/July 2012, Cilt/Vol: 14, Say1/Num:3, Page: 65-80

ISSN: 1303-2860, DOI: 10.4026/1303-2860.2012.0206.x

Makalenin on-line kopyasına erişmek için:

http://www.isguc.org/?p=article\&id=484\&vol=14\&num=3\&year=2012

To reach the on-line copy of article:

http://www.isguc.org/?p=article\&id=484\&vol=14\&num=3\&year=2012

Makale İçin İletişim/Correspondence to: 
(c) 2000- 2012

“İşGüç” Endüstri İlişkileri ve İnsan Kaynakları Dergisi

"İşGüç" Industrial Relations and Human Resources Journal

Temmuz/July 2012, Cilt/Vol: 14, Say1/Num: 3

ISSN: 1303-2860, DOI: 10.4026/1303-2860.2012.0206.x

İş,Güç, Endüstri İlişkileri ve İnsan Kaynaklanı Dergisi, yılda dört kez yayınlanan hakemli, bilimsel elektronik dergidir. Çalışma hayatına ilişkin makalelere yer verilen derginin temel amacı, belirlenen alanda akademik gelişime ve paylaşıma katkıda bulunmaktadır.

İş, Güç, Endüstri İlişkileri ve İnsan Kaynakları Dergisi, 'Türkçe' ve 'İngilizce' olarak iki dilde makale yayınlanmaktadır. Dergi ulusal ve uluslar arası birçok indekste taranmaktadır. (CABELLS DIRECTORY, EBSCO SOCINDEX , INDEX ISLAMICUS, INDEX COPERNICUS, WORLDWIDE POLITICACAL SCIENCE ABSTRACTS, SOCIOLOGICAL ABSTRACT, ULAKBIMM SOSYAL BİLIMLER VERITTANI, ASOS INDEX)

Editör/Editor-in-Chief

Aşkın Keser (Uludağ University)

Editör Yardımcıları/Co-Editors

K.Ahmet Sevimli (Uludağ University)

Gözde Yilmaz (Marmara University)

Uygulama/Design

Yusuf Budak (Kocaeli Universtiy)

Tarandiğı Indeksler

ASOS INDEX

CABELLS DIRECTORY

EBSCO SOCINDEX

Index ISLAMICUS

Index COPERNICUS

Sociological Abstract

ULAKBİM Sosyal Bilimler

Veritanı

Worldwide Political Science

Abstracts
Yayın Kurulu / Editorial Board

Dr. Erdem Cam (ÇASGEM)

Dr. Zerrin Firat (Uludă̆ University)

Doç. Dr. Aşkın Keser (Uludağ University)

Prof. Dr. Ahmet Selamoğlu (Kocaeli University)

Yrd. Doç. Dr. Ahmet Sevimli (Uludă̆ University)

Doç. Dr. Abdulkadir Șenkal (Kocaeli University)

Doç. Dr. Gözde Yılmaz (Marmara University)

Dr. Memet Zencirkıran (Uludă̆ University)

Uluslararası Danışma Kurulu / International Advisory Board Prof. Dr. Ronald Burke (York University - CA)

Assoc. Prof. Dr. Glenn Dawes (James Cook University - AU)

Prof. Dr. Jan Dul (Erasmus University - NL)

Prof. Dr. Alev Efendioğlu (University of San Francisco - USA)

Prof. Dr. Adrian Furnham (University College London - UK)

Prof. Dr. Alan Geare (University of Otago - NZ)

Prof. Dr. Ricky Griffin (TAMU-Texas AEM University - USA)

Assoc. Prof. Dr. Diana Lipinskiene (Kaunos University - LT)

Prof. Dr. George Manning (Northern Kentucky University - USA)

Prof. Dr. William L. Murray (University of San Francisco - USA)

Prof. Dr. Mustafa Özbilgin (Brunel University - UK)

Assoc. Prof. Dr. Owen Stanley (James Cook University - AU)

Prof. Dr. Işık Urla Zeytinoğlu (McMaster University - CA)

Ulusal Danışma Kurulu / National Advisory Board

Prof. Dr. Yusuf Alper (Uludă̆ University)

Prof. Dr. Veysel Bozkurt (İstanbul University)

Prof. Dr. Toker Dereli (Işık University)

Prof. Dr. Nihat Erdoğmuş (Şehir University)

Doç. Dr. Mustafa Kurt (Yalova University)

Prof. Dr. Ahmet Makal (Ankara University)

Prof. Dr. Süleyman Özdemir (İstanbul University)

Prof. Dr. Ahmet Selamoğlu (Kocaeli University)

Prof. Dr. Nadir Suğur (Anadolu University)

Prof. Dr. Nursel Telman (Maltepe University)

Prof. Dr. Cavide Uyargil (İstanbul University)

Prof. Dr. Engin Yildirim (Constitutional Court of Turkey)

Doç. Dr. Arzu Wasti (Sabancı University)

Dergide yayınlanan yazılardaki görüşler ve bu konudaki sorumluluk yazarlarma aittir.

Yayınlanan eserlerde yer alan tüm içerik kaynak gösterilmeden kullanılamaz.

All the opinions written in articles are under responsibilities of the outhors.

The published contents in the articles cannot be used without being cited. 


\title{
Beyaz Yakalıların Tanımlanması Üzerine*
}

\author{
On The Definition Of White Collar Workers
}

\author{
A. Utku ERDAYI \\ Araş.Gör.Dr., Marmara Üniversitesi, İktisadi ve İdari Bilimler Fakültesi, Çalışma \\ Ekonomisi ve Endüstri İlişkileri Bölümü
}

\begin{abstract}
Özet
"Beyaz yakalılar" kavramının hangi çalışanları kapsadığı konusunda ciddi bir belirsizlik vardır. Söz konusu belirsizlik nedeniyle beyaz yakalılar kavramının tanımlanması bir sorun halini almıştır. Bu çalışma, beyaz yakalıların tanımlanması konusundaki belirsizliği bir ölçüde gidermeyi ve beyaz yakalıların tanımlanmasına iliş̧kin yeni tartışmalara olan ihtiyaca dikkat çekmeyi amaçlamaktadır. Belirtilen amaçlar bağlamında, beyaz yakalıların tanımlanmasına ilişkin literatürdeki yaklaşımlar incelenerek beyaz yakalıları, diğer çalı̧̧anlardan ayırt etmeye yarayan ortak ölçütlere ulaşılmaya çalışılmıştır. Bu güne kadar, doğrudan beyaz yakalıları tanımlama girişiminde bulunan dört yaklaşımdan söz edilebilir. Bunlar zihin-kas yaklaşımı, fonksiyonel yaklaşım, eklektik yaklaşım ve eleştirel yaklaşımdır. Sayılan yaklaşımlardan hareketle beyaz yakalıların tanımlanması ile ilgili ǚç temel ölçüte ulaşılmıştır: Kol/kas gücüne baskın bir biçimde kafa/zihin gücüne dayalı olarak çalışmak, eğitimli olmak ve genellikle sembolik olmakla birlikte, otoriteye yakın ya da otorite sahibi olmaktır.
\end{abstract}

Anahtar Kelimeler: Beyaz Yakalı İşçiler, Beyaz Yakahlar, Kol Gücüne Dayanmayan, Kafa Gücüne Dayanan, Büro İş̧ileri

\begin{abstract}
There is a serious ambiguity about the content of the "white-collar workers" concept that include which type of employees. Because of that ambiguity describing the white-collar workers concept become a issue. This study aims to attract attention to lack of a new discussion concerning the definition of white-collar workers and to remove ambiguity about the description of white-collar workers to a certain extent. In this regard this paper examines the approaches which try to define the white-collar workers and tries to reach the comman criteria that differentiate the white-collar workers from the other employees. Up till now there are four approaches which try define the whitecollar workers. These are brain-brawn approach, functional approach, eclectic approach and critical approach. When we take these appoaches in consideration we can reach three basic criteria about defining the white-collar workers: Working by intellectual/brain predominantly rather than by manual/brawn, beign educated and proximity to authority or possession of authority which is generally sembolic.
\end{abstract}

Keywords: White-Collar Workers, White Collars, Non-Manual, Intellectual, Clerical Workers

\footnotetext{
* Bu çalışma "Beyaz Yakalı İşçilerde Örgütlenme: Türk Bankacılık Sektöründe Bir Alan Araştırması" adlı doktora tezinin teorik kısmından yararlanılarak hazırlanmıştır.
} 


\section{Giriş}

İstihdamın, ağırlıklı olarak 1980'li yıllardan itibaren hizmetler sektörüne kayması ile birlikte mavi yakalıların istihdamdaki payı azalırken, beyaz yakalıların ${ }^{1}$ istihdamdaki payı artış göstermiştir. Batılı ülkelerin tümünün resmi istatistiklerinde, beyaz yakalıların işgücü içerisindeki payı görece fazladır ve artış eğilimi sürmektedir. Diğer ülkelerdeki beyaz yakalıların işgücü içerisindeki oranının ise, Batılı ülkeler kadar yüksek olmamakla birlikte, onlara benzer bir eğilim göstererek arttığ 2005:55). Beyaz yakalıların işgücü içerisindeki payının artışına koşut olarak yüksek ücret, iş güvencesi, işverenle kurulan yakın ilişkiler, özerklik, saygınlık gibi tarihsel olarak görece sahip oldukları imtiyazları tedrici olarak aşınmıştır. Bugün beyaz yakalıların büyük çoğunluğu, çalışma koşulları bakımından mavi yakalılardan farksız görünmektedir. Çalışma koşulları görece iyi olan azınlıktaki beyaz yakalıların ise, mevcut koşulları her geçen gün mavi yakalılara yaklaşmaktadır. Bu gelişmeler bağlamında, 21. yüzyılda işçi sınıfının en büyük bileşeninin ve emek tartışmalarında en fazla yer tutacak çalışanların beyaz yakalılar olması muhtemel görünmektedir.

Ücretli emek içerisinde hem nicel olarak, hem de çalışma koşulları itibariyle böylesine önemli hale gelen "beyaz yakalılar" kimdir? Bu soruya henüz tatmin edici bir cevap bulunmamış/bulunamamıştır. Esasen "beyaz yakalıların kim olduğu" sorusu yeni bir soru değildir. 20. yüzyıl boyunca bu soruya cevap aranmış ve beyaz yakalı işlerin/mesleklerin neler olduğuna ilişkin tartışmalar yaşanmış$\mathrm{t}^{2}{ }^{2}$. Ancak beyaz yakalıların genel kabul gören net bir tanımına ulaşılamamıştır. Ya- zında ve günlük dilde sıklıkla kullanılan "beyaz yakalılar" teriminin eğitimli, iyi ücret alan, yönetimin üst kademelerine yakın, şık giyimli gibi belli özelliklere ilişkin çağrışımlar yaptığ1 söylenebilir. Bununla birlikte, aşağıda görüleceği gibi, beyaz yakalıların kendilerine has özelliklerini ortaya koyan ve beyaz yakalılar gurubuna giren çalışanların sınırlarını kesin biçimde çizen net bir tanım yapmak gerçekten kolay değildir.

Bu çalışma, beyaz yakalılarla ilgili mutlak bir tanıma ulaşmak iddiası taşımamaktadır. Ancak en azından, tanımlama konusundaki belirsizliğin bir ölçüde giderilmesi amaçlanmaktadır. Bundan daha önemli bir amaç ise, 21. yüzyılda işçi sınıfının temel bileşeni olacakları görülebilen beyaz yakalıların ya da Tanıl Bora'nın (2010:49) beyaz yakalıların durumlarını çarpıcı biçimde özetleyen ifadesiyle "mavileşen beyaz yakalılar"ın tanımlanmasına ilişkin yeni tartışmalara olan ihtiyaca dikkat çekmektir. Bu bağlamda, öncelikle beyaz yakalıların bir sorun haline gelen tanımlanma güçlüğünden bahsedilecektir. Daha sonra, beyaz yakalıları tanımlamaya yönelik yaklaşımlara yer verilerek beyaz yakalılar ve beyaz yakalı işler/mesleklerle ilgili genel bir çerçeve çizilecektir. Son olarak ise, beyaz yakalılarla ilgili bir tanıma ulaşılmaya çalışılacaktır.

Beyaz yakalılarla ilgili tartışmalar, 20. yüzyılın başından bu yana, yer yer birbiriyle iç içe geçen iki temel alanda yürütülmüştür. Tartışma alanlarından ilki, genellikle beyaz yakalıların sınıfsal konumlarına göndermeler yapmaksızın sadece tanımlanması, kimleri kapsadığının belirlenmesi ve beyaz yakalı işlerin/mesleklerin neler olduğunun ortaya konulması amaçlarına yönelik girişimleri kapsamaktadır³. İkinci tartışma alanı,

1 İngilizcede "beyaz yakalılar" teriminin karşılığ olarak “white-collar workers" (beyaz yakalı işçiler), “white-collar employees" (beyaz yakalı çalışanlar) ya da "white collars" (beyaz yakalılar) terimleri kullanılmaktadır. "White collars" terimi İngilizcede nadir kullanılmakta ve akademik metinlerde tercih edilmemektedir. Bu çalışmada, beyaz yakalıların büyük bir çoğunluğunun işçi olduğu kabul edilmekle birlikte, küçük bir azınlığının işçi olmadığı ve "beyaz yakalılar" teriminin İngilizcenin aksine Türkçe akademik metinlerde yaygın olarak kullanıldığı göz önüne alınarak "beyaz yakalı işçiler" yerine, "beyaz yakalılar" teriminin kullanımı tercih edilmiştir

2 Doğrudan "Beyaz yakalılar kimdir?" sorusunun sorularak cevap arandığı tartışmalar için bkz. Jenkins ve Sherman, 1979:12-22; Bain ve Price, 1972.

3 Beyaz yakalıların tanımlanmasına ve beyaz yakalı işlerin/mesleklerin neler olduğunun belirlenmesine ilişkin çabalar konusunda bkz. Hyman ve Price, 1983:3-15; Bain ve Price, 1972. 
beyaz yakalıların sinıfsal konumlarının tespit edilmesi amacına odaklanmış olan ve ilk tartışma alanına kıyasla daha önemli ve kapsamlı kabul edilebilecek tartışmaları içermektedir ${ }^{4}$. İkinci tartışma alanı esasen ilkine k1yasla daha önemli olmakla birlikte, bir makalenin hacmini ve amacını aşan tartışmaları içermektedir. Dolaysıyla ancak kapsamlı bir çalışmaya konu olabilecek beyaz yakalıların sınıfsal konumlarına ilişkin tartışmaların, bu çalışmanın kapsamı dışında olduğu şimdiden belirtilmelidir.

\section{Beyaz Yakalıların Tanımlanması Sorunu}

20. yüzyılın ilk yarısından itibaren, genel bir bakışla mavi yakalılardan farklı oldukları söylenebilen, ancak kim oldukları ve kendilerine has nitelikleri net bir biçimde ortaya konulamayan beyaz yakalıları tanımlamaya yönelik çeşitli girişimler olmuştur. $\mathrm{Bu}$ girişimlerin hepsinde, beyaz yakalıların tanımlanmasında ciddi güçlükler olduğu ifade edilmiştir. Dolayısıyla öncelikle bir problem haline gelen beyaz yakalıların tanımlaması konusundaki zorluktan ve söz konusu zorluğun arkasındaki nedenlerden bahsetmek gerekmektedir.

Beyaz yakalılar teriminin belirsiz bir terim olduğu öteden beri dile getirilmektedir (Hyman ve Price, 1983:14; Jenkins ve Sherman, 1979:12; Bain ve Price, 1972:325; Mills, 1951:241). Bugün halen söz konusu belirsizlik sürmekte, beyaz yakalılar denilince farklı çalışan gruplarından biri ya da bir kaçı akla gelebilmektedir. Örneğin beyaz yakalılar denildiğinde mimarlar, mühendisler, teknisyenler gibi teknik işlerde çalışanlar ya da yöneticiler ve denetçiler gibi üst düzey çalışanlar veya büro işçileri gibi rutin işleri yürüten çalışanlardan sadece biri ya da birkaçı akla gelebilmektedir. Yine beyaz yakalılardan bazen kamu çalışanları anlaşılırken, bazen de hizmet sektörü çalışanlarının tümü anlaşılabilmektedir.

"Beyaz yakalılar" terimi ülkeler arasında da farklı anlamlara gelebilecek şekilde kul- lanılmakta, bu terim yerine "maaşlı çalışanlar", "kol gücüyle çalışmayanlar", "büro işçileri" gibi farklı terimlerin kullanıldığ 1 görülmektedir. Bir ülkede beyaz yakalı olarak kabul edilen bir meslek grubu, diğer ülkede farklı bir kategori içerisinde yer alabilmektedir (Hyman ve Price, 1983:9-10). Hatta Türkiye gibi bazı ülkelerin resmi istatistiklerinde "beyaz yakalılar" kategorisi bulunmamaktadır. Gerçekten Türkiye'nin resmi istatistiklerinde "beyaz yakalılık" ya da "kol gücüyle çalışmama" göndermeleri olmaksinız "profesyonel meslek mensupları" ya da "büro ya da müşteri hizmetlerinde çalışan elemanlar" (TÜİK, 2011) gibi ifadeler kullanılmaktadır. Türkiye'de böyle adlandırılan çalışan grupları, örneğin İngiltere gibi başka ülkelerde, "beyaz yakalılar" ya da "kol gücüyle çalışmayanlar" kategorisi altında sayılmaktadır (Hyman ve Price, 1983:11).

Beyaz yakalıların tanımlanması konusundaki belirsizliğin iki temel nedeninden bahsedilmektedir. İlk olarak beyaz yakalıların çalıştıkları yerler, iş ortamları, ücretlerinin ödenme yöntemleri, çalışırken giydikleri elbiselerin türü gibi özelliklere göndermeler yapılarak tanımlanması ya da bunlar üzerinden anlaşılması net bir tanımın yapılmasını güçleştirmektedir. Çünkü sayılan özelliklerin, sadece görünürdeki ve değişken nitelikler olduğu ifade edilmektedir (Bain ve Price, 1972:325). İkincisi, beyaz yakalıların tanımına ilişkin belirsizliğin büyük oranda, yürüttükleri işlerin son derece heterojen bir yapıya sahip olmasından kaynaklandığ 1 belirtilmektedir (Callinicos ve Harman, 2006:30; Hyman ve Price, 1983:13; Bain ve Price, 1972:326). Beyaz yakalı meslekler yönetim, denetim, pazarlama gibi işletme fonksiyonlarına gönderme yapan yöneticilik, denetçilik vb. meslekleri kapsadığı gibi; mühendislik, mimarlık vb. profesyonel teknik meslekleri de kapsamakta; hatta serbest çalışan profesyoneller olarak avukatlar, muhasebeciler ya da çeşitli danışmanları içerisine aldığı gibi; bankacılık, sigortacılık vb. rutin

4 Doğrudan beyaz yakalıların sınıfsal konumlarına ilişkin tartışmalar hakkında bkz. Sobel, 1989; Hyman ve Price, 1983; Mills, 1951. Ayrıca söz konusu tartışmaların derli toplu bir hali için bkz. Erdayı, 2012: 39-68. 
büro işlerinin ağırlıklı olduğu meslekleri de içerebilmektedir. Bu haliyle beyaz yakalı olarak kabul edilen sektörler, Mills'in (1951:291) ifadesiyle "mesleki salata"ya benzemektedir. Beyaz yakalı mesleklerdeki heterojenlik, beyaz yakalı işlerin bir bütün olarak doğasının ortaya konulmasını ve söz konusu işlere ilişkin genel açıklamalar yapılmasını zorlaştırarak ciddi bir belirsizliğe yol açmaktadır (Bain ve Price, 1972:326).

Beyaz yakalıların, işlerinin doğası ve kendilerine özgü nitelikler üzerinden tanımlanmasında karşılaşılan güçlük, onların mavi yakalıların karşıtı olarak tanımlanması sonucunu doğurmuştur (Bain ve Price, 1972:326). Beyaz yakalıların karşıtı üzerinden tanımlanması tanım problemini çözmemektedir. Mavi yakalı işler ya da mavi yakalılar denildiğinde hangi tür işlerin ya da hangi grubun kastedildiği az çok anlaşılmaktadır. Mavi yakalı işlerden imalat, madencilik, inşaat, makine yapımı, onarımı ve bakımı, montaj gibi alanlardaki kol gücüne dayalı, çalışma koşullarının ağır olduğu, tehlikeli ve eğitim gerektirmeyen işler anlaşılmaktadır. Beyaz yakalılar, mavi yakalıların karşıtı olarak kavrandığında, örneğin kol gücüne dayanmayan çalışanlar şeklinde tarif edildiğinde, mavi yakalılar dışında kalan ve birbirleriyle fazla ortak yanı bulunmayan çalıșanların tümünü beyaz yakalı olarak nitelendirmek mümkündür. $\mathrm{Bu}$ durum belirsizliği gidermediği gibi, beyaz yakalı işlerin/mesleklerin sinırlarının çizilmesini daha da zorlaştırmaktadır. Örneğin mavi yakalılar gibi ağır bir işi yüklenmeyen ve kol gücüne dayalı olarak çalışmayan bir "aşçı" beyaz yakalı mıdır? Ya da mavi yakalılar gibi eğitimli olmayan ancak küçük bir kumanda koluyla metroyu kullandığ 1 için kol gücüyle çalıştığı da söylenemeyen "vatman" beyaz yakalı mıdır? Başka bir açıdan bakıldığında ise, beyaz yakalı olarak kabul edilen ve rutin işleri yürüten bir büro işçisinin mavi yakalıların aksine çalışma koşullarının hafif olduğu söylenebilir mi? Ayrıca rutin büro işlerinin niteliksizleşmesine bağlı olarak ciddi bir eğitim gerektirip gerektirmediği sorusu akla gelmekte ve kafa gücüyle çalışılıp çalışılmadığı tartışılmaktadır 5 .

Beyaz yakalıların, mavi yakalıların karşıtı olarak tanımlanmasının, onların sinıfsal konumuyla ilgili yanlış bir algıyı beraberinde getirdiği de yeri gelmişken belirtilmelidir. Esasen giriş bölümünde sınıfsal konuma ilişkin tartışmalara girilmeyeceği ifade edilmiştir. Ancak söz konusu yanlış alg1, hem beyaz yakalıların tanımlanması ile doğrudan bağlantılı olması, hem de yaygin olması nedeniyle büyük önem taşımaktadır. Dolayısıyla atlamamak adına burada sadece tespit edilerek geçilecektir. Mavi yakalıların işçi sınıfı ile özdeş olduğuna ilişkin yaygın bir kanı vardır. Mavi yakalıların, özellikle sınıf mücadelesi anlamında sahip olduğu tarihsel mirastan kaynaklanan söz konusu kanı, genellikle mavi yakalıların karşıtı olarak tanımlanan ya da anlaşılan beyaz yakalıların, işçi sınıfının bir parçası olmadığı gibi bir yanılsamaya yol açmaktadır. Hâlbuki kişilerin nesnel olarak ait oldukları sinıf, onların beyaz ya da mavi yakalı, üretken ya da üretken olmayan, sözleşmeli ya da kadrolu gibi farklı kategorilere dâhil olmalarını sağlayan kriterlerin ötesinde, üretim araçlarının mülkiyetine sahip olup olmadıkları ve üretim süreci içerisinde kontrol ve denetim gücü gibi esasen kapitaliste ait fonksiyonları üstlenip üstlenmedikleri üzerinden belirlenmektedir.

\section{Beyaz Yakalıları Tanımlamaya Yönelik Yaklaşımlar}

Beyaz yakalılara ilişkin görüşlerin ortaya atılması, 20. yüzyıl ile birlikte başlamıştır. Ancak esas tartışmalar, beyaz yakalıların iş-

\footnotetext{
5 Braverman, büro çalışmasında zihinsel faaliyetin tamamen ortadan kalkmadığını, ancak zihinsel süreçlerin tekrara ve rutine bağlandığını ya da iş sürecinin bütünü içerisinde çok küçük bir öğeye indirgendiğini belirtmektedir. İş sürecinde, işlemlerin elle yapılabilecek parçasının zihinsel faaliyetten arınarak ne kadar hızlı yapılacağının, bir bütün olarak emek sürecine egemen olduğunu ifade etmektedir. Braverman, bu haliyle büro çalışmasının, kol gücüne dayandığını iddia etmektedir (2008:302). Büro çalışmasının kol gücüne dayalı hale gelmesi konusundaki tartışma için bkz. Braverman, 2008:296-302.
} 
gücü içerisindeki artışının dikkat çekici hale geldiği ve sendikal anlamda örgütlenmeye başlayarak önem kazandıkları 20. yüzyılın ikinci yarısına rastlamaktadır. 20. yüzyıl içerisinde, doğrudan beyaz yakalıları tanımlama çabasında olan dört yaklaşımdan bahsedilebilir. Bunlar zihin-kas yaklaşımı, fonksiyonel yaklaşım, eklektik yaklaşım ve eleştirel yaklaşımdır. Aşağıda bu yaklaşımların temel iddiaları açıklanacaktır.

\section{Zihin-Kas Yaklaşımı}

Zihin-kas yaklaşımı, tarihsel olarak beyaz yakalıları tanımlamada kullanılan en popüler yaklaşımdır. 20. yüzyılın başlarında ortaya atılan bu yaklaşımla birlikte "beyaz yakalı" terimi, zihinsel çaba sarf eden çalışanları tanımlamak amacıyla kullanılmıştır. Zihin-kas yaklaşımında "beyaz yakalı" terimi, minimum düzeyde eğitim ve doğrudan yüksek kas gücü ya da fiziksel çaba gerektiren mavi yakalı işler ile zihinsel çaba gerektiren büro işlerini birbirinden ayırmak ve söz konusu işleri yürüten çalışanlar arasındaki ayrımı belirginleştirmek amacıyla kullanılmıştır (Bain ve Price, 1972:327). Zihin-kas yaklaşımı ile birlikte, çalışırken zihinsel çaba/beyin gücü veya fiziksel çaba/kas gücü harcanmasına bağlı olarak belirlenen beyaz-mavi yakalı ya da kafa-kol gücüne dayalı çalışanlar ayrımı, 20. yüzyılın başlarından günümüze kadar kullanılarak gelmiştir.

Zihin-kas yaklaşımının öncüsü, Alman sosyolog Emil Lederer'dır. Lederer 1912 y1linda yayınlanan eserinde, zihin-kas yaklaşımı ile ilgili fikirlerini ortaya koyarak beyaz yakalıların tanımlanması konusunda ilk açıklamaları yapan düşünür olmuştur. Ona göre, beyaz yakalılar konum olarak, ücretli işçiler ile bağımsız çalışanlar arasında bulunan bir çalışan grubunu ifade etmektedir. Bu belirlenim üzerinden beyaz yakalı meslekleri tespit etme girişiminde bulunan Lederer, beyaz yakalı olarak kabul edilen mesleklerin heterojenliğinin farkına varmıştır. Lederer'a göre, söz konusu heterojenlik, beyaz yakal1ların yaptıkları işlerin doğasına ilişkin pozi- tif kriterler koyarak tanım yapmayı güçleştirmektedir. Zaten beyaz yakalıların, pozitif kriterlerden ziyade, toplumdaki saygınlıkları ve kendi bilinçleri tarafından şekillenen sosyal karakterleri tarafindan anlaşıldı ğını ifade etmiştir (Lederer'dan aktaran Mills, 1951:241-242). Lederer, pozitif kriterler belirlemek konusundaki güçlük nedeniyle beyaz yakalıları, "salt kol gücüne dayanan işlerin dışında kalan işlerde çalışanlar", başka bir ifadeyle mavi yakalılar dışında kalan çalışanlar olarak tanımlamıştır (Lederer'dan aktaran Bain ve Price, 1972:326). Lederer'ın beyaz yakalıların eğitim, prestij, ücret gibi özellikler bakımından daha avantajlı olduklarına, dolayısıyla bu kriterlerin de beyaz yakalıların tanımlanmasında kullanılması gerektiğine dikkat çektiği belirtilmiştir (Sobel, 1989:25).

Lederer'in, beyaz yakalıları, temelde kol gücüne dayanan işlerin dışında kalan işlerde çalışanlar olarak tanımlaması, aslında çok geniş ve birbiriyle fazla ortak yanı olmayan bir çalışan kitlesini beyaz yakalılar kategorisine sokmuş olması anlamina gelmektedir. Dolayısıyla böyle bir girişimle beyaz yakalıların kimler olduğuna ilişkin belirsizliğe çözüm bulmuş değildir. Bununla birlikte, Lederer'ın beyaz yakalı işleri, kol gücüne dayalı mavi yakalı işlerin dışında kalan işler olarak tanımlaması, kendisinden sonra bu işlerin zihinsel çabaya dayalı ve kol gücü gerektirmeyen işler olarak anlaşılmasına hizmet etmiştir.

Gerçekten beyaz yakalıların bu şekildeki belirlenimi, yaygın biçimde kabul görmüştür. Öncelikle birçok endüstri ilişkileri ders kitabında, zihin-kas yaklaşımının yansıması olan beyaz yakalı işlerin zihin gücüne dayalı "kafa işleri" olduğu, bu işleri yerine getirenlerin de "beyaz yakalılar" olduğu görüşü benimsenmiştir. Örneğin, Edwin Beal ve Edward Wickersham'ın 1963 yılında yayınlanan "Toplu Pazarlık Uygulamaları" adlı eserlerinde, "...beyaz yakalıların, kollarından ziyade kafalarıyla çalışarak hayatlarını devam ettirdikleri, beyaz yakalı işlerin de beyin gücüne dayalı işler olduğu ve çeşitli 
yoğunlukta zihinsel faaliyet gerektirdiği" kabul edilmiştir (Beal ve Wickersham'dan aktaran Bain ve Price, 1972:327). Bu kavran1lıș biçimiyle "beyaz yakalı" teriminin, akademik tartıșmalara konu olmakla ve endüstri ilişkileri kitaplarına girmekle kalmadığı, 1927 yılında Uluslararası Çalışma Örgütü'nün resmi metinlerine beyaz yakalıların "fiziksel çabadan ziyade, zihinsel çaba gerektiren emek" şeklinde girerek kurumsal olarak kullanıldığı ve Almanya, Avusturya, İsveç gibi birçok ülkenin resmi metinlerinde benimsendiği görülmektedir (Bain ve Price, 1972:327).

Aslına bakılırsa, insan emeğinin hiçbir biçiminin kafa ve kol arasında belli ölçüde bir birlik olmadan gerçekleşmesi mümkün değildir (Sohn-Rether, 2011:98). Yapilan herhangi bir işte sarf edilen zihinsel ya da fiziksel çabayı birbirinden ayırmak mümkün olmadığına göre, zihinsel ya da fiziksel çaba gerektiren işleri de net bir biçimde birbirinden ayırmak olanaksızdır. Her iş belli oranlarda bu iki tür çabayı gerektirdiğinden, ancak bir çabanın diğerine ağır bastığını söylememiz mümkündür. Bu bağlamda beyaz yakalı işler, fiziksel çabaya baskın bir biçimde zihinsel çaba gerektiren etkinlikleri kapsayan işler olarak kabul edilebilir. Zihinkas yaklaşımından hareketle beyaz yakalı işlerin bu șekildeki kavranılıșı, beyaz yakalılara ilişkin tartışmaların büyük çoğunluğuna damgasını vurmuştur.

\section{Fonksiyonel Yaklaşım}

Fritz Croner tarafından 1950'li yıllarda ileri sürülen fonksiyonel yaklaşım, beyaz yakalılarin tanimlanması meselesine daha tatmin edici bir açıklama getirme iddiası taşımaktadır. Croner, beyaz yakalı işleri eğitim, prestij gibi kriterlerle tanımlamamıștır. Çünkü ona göre, söz konusu kriterler az ya da çok sübjektif nitelik taşımaktadır. Onun analizinin, işin içeriğine ilişkin objektif yönleri temel almayı amaçladığı belirtilmiştir (Bain ve Price, 1972:331). Croner'1n, beyaz yakalılarla ilgili yaklaşımının temelinde "yetkilendirme teorisi" bulunmaktadır.
Buna göre, liderlik ve yönetim fonksiyonlarının parçalanması, beyaz yakalıların belli oranda yetkilendirilmesini ve söz konusu fonksiyonların, yetkilendirilen beyaz yakalılara aktarılmasını gerekli kılmıştır (Hyman ve Price, 1983:48). Sermaye birikiminin genişlemesine koşut olarak, çoğunluğu yönetime ilişkin fonksiyonlar çeşitlenerek yürütülemez hale gelecek kadar artmıştır. Bu durum, söz konusu fonksiyonların parçalanarak ücretli çalışanlara devredilmesini zorunlu kıldığ 1 gibi, kapitaliste ait otoriter yetkilerin büyük bir bölümünün de aynı ücretli çalışanlara aktarılmasını gerektirmiştir. Croner için, sermaye adına zorunlu olarak yetkilendirilen bu ücretli grup beyaz yakalılardir (Sobel, 1989:18).

Croner, beyaz yakalıları, yerine getirdikleri fonksiyonlar aracılığıyla tanımlamaktadır. Ona göre, beyaz yakalıların yürüttügü bu fonksiyonlar dört ana başlık altında toplanmaktadır:

(1) İdari fonksiyonlar: Genel yönetime ilişkin işler, yasal-politik işler, sağlık ve refaha ilişkin işler, eğitim ve öğretime ilişkin işler, finansal işler, yazışma/haberleşme işleri, bilgi-işlem işleri.

(2) Tasarm, analiz ve planlama fonksiyonlart: Bilimsel, deneysel, istatistiksel ve fikir/düşünce ile ilgili işler, mal üretimine ilişkin işler, sanatsal işler.

(3) Yönetim ve denetim fonksiyonları: Üretim yönetimine ilişkin işler, hizmet ve ticaret yönetimine ilişkin işler.

(4) Ticari fonksiyonlar: Nakliye ve diğer tüm ticari işler (Croner'dan aktaran Bain ve Price, 1972:331-332).

Croner'a göre bu dört fonksiyon, beyaz yakalı istihdamın ayırt edici özelliğidir. Çünkü beyaz yakalılar tarafından yerine getirilen bu fonksiyonlar, sanayi devrimi sonrasına rastlayan kapitalist gelişmenin erken evrelerinde işverenler tarafından yürütülmüştür. Esasen bu fonksiyonlar, yönetim ve organizasyon ile ilgilidir ve büro, muhasebe, idare, satın alma, pazarlama, denetim, plan- 
lama işlerini ve teknik görevleri içermektedir. Croner'a göre, genel olarak işverenin sorumluluğunda olan bu farklı işler, işletmelerin çok büyümesi ve yerine getirilecek görevlerin karmaşıklaşması nedeniyle yukarıda sayılan ana fonksiyonlar altında toplanarak beyaz yakalı emeğe yüklenmiştir. Dolayısıyla söz konusu fonksiyonların, beyaz yakalıları karakterize ettiğini ve onların tanımlanmasına temel oluşturduğunu belirtmektedir (Croner'dan aktaran Bain ve Price, 1972:332).

Belirtildiği gibi, sermaye birikiminin artmasina paralel olarak sermayedarlar tarafından yerine getirilen fonksiyonlara ait işlerin, artık yürütülemeyecek kadar artması, çeşitlenmesi ve karmaşıklaşması, söz konusu işleri yerine getirecek yeni bir ücretli işçi kategorisi ortaya çıkarmıştır. İşte Croner, sermayenin genişlemesinin sonucu olarak ortaya çıkan bu işleri yürüten ücretlileri, yerine getirdikleri fonksiyonlar üzerinden beyaz yakalılar olarak tanımlamaktadır. Bu yönüyle fonksiyonel yaklaşım, beyaz yakal1ların tanımı konusunda, zihin-kas yaklaşımina oranla sinırları belirli bir tablo ortaya koymuştur. Çünkü beyaz yakalıların yerine getirdiği belirtilen fonksiyonlar, onların kimler olduğu konusunda, "kol gücüyle çalışmayanlar" ya da "kol gücüyle çalışanlar dişında kalanlar" gibi ifadelerden daha net bir fikir vermektedir. Bunun yanı sıra fonksiyonel yaklaşımda, zihin-kas yaklaşımından farklı olarak, karşıtı üzerinden bir tanımlama yerine, ilk defa beyaz yakalı işlerin yapısina ve beyaz yakalıların yerine getirdiği fonksiyonlara ilişkin açıklamalar yapılarak, doğrudan beyaz yakalıları tanımlamaya yönelik bir çaba sergilenmiştir. Bu önemlidir, çünkü daha önce vurgulandığ1 gibi, beyaz yakalıların kimler olduğu konusundaki belirsizliğin temel nedeni, beyaz yakalıların kendilerine ve işlerinin doğasına ilişkin doğrudan açıklamalar yapılarak tanımlanması yerine, karşıtı olarak kabul edilen mavi yakalılar üzerinden tanımlanmasıdır.

Fonksiyonel yaklaşımın, sayılan olumlu yönlerine rağmen, başka sorunları beraberinde getirdiği belirtilmelidir. Beyaz yakalı mesleklerin heterojenliği nedeniyle beyaz yakalıların çok çeşitli ve değişken fonksiyonları üstlendikleri bilinmektedir. Beyaz yakalılar üstlendikleri fonksiyonlar üzerinden tanımlandığında, bu sefer de söz konusu fonksiyonların net bir biçimde belirlenmesi sorunu ortaya çıkmaktadır. Çünkü üretim sürecinin aşırı derecede parçalanması nedeniyle ortaya çıkan çok sayıda ve birbiriyle iç içe geçmiş fonksiyonları açıkça belirlemek kolay değildir.

\section{Eklektik Yaklaşım}

Bahsedilen diğer iki yaklaşıma kıyasla eklektik kabul edilebilecek bir yaklaşım, 1961'de Roger Girod tarafından ileri sürülmüştür. Eklektik yaklaşım, zihin-kas ayrımını kabul etmekte, ancak bu ayrıma ek olarak beyaz yakalıların bazı kriterler bak1mindan da mavi yakalılardan ayrılabileceğini iddia etmektedir. Girod, yaptığ1 incelemeler sonucunda, beyaz yakalıları, kol işçilerinden ayıran iki kriter olduğu sonucuna ulaşmıştır. Bunlardan ilki çalışma ortamının yapısıdır. Girod, çalışma ortamını sadece fiziksel şartlar üzerinden değerlendirerek iki tip çalışma ortamı belirlemiştir. Buna göre kol gücüyle çalışan işçilerin çalışma ortamı "mekanik", beyaz yakalıların çalışma ortamı "bürokratik" veya "mekanik olmayan"dır. Bunun yanında, kol gücüyle çalışmayan tüm işçilerin çalıştıkları çevreler "burjuvaya özgü" nitelik taşıyan yerlerdir. Kol gücüyle çalışan işçilerin çalıştıkları yerler ise, burjuvaya özgü yerlerin tamamen d1şında kalmaktadır (Girod'tan aktaran Bain ve Price, 1972:335).

Girod'un ikinci kriteri, çalışmanın işlevi ve amacıdır. Bu kriter, mesleklerin işlevleri ve amaçları temelinde belirlenmiştir. Girod'a göre, iki etkinlik alanı vardır: İlki, insanlar üzerindeki eylemi, ikincisi nesneler üzerindeki eylemi içerir. Çalışanlar; insanlar ve nesneler üzerindeki işlevleri yerine getirirken insana yönelik amaçlar ve nesneye yönelik amaçlar doğrultusunda hareket 
ederler. İşte kol gücüyle yapılan işler nesneye yönelik amaçlar taşır ve kullanılabilir bir şey yaratma işlevini yerine getirir; kol gücüne dayanmayan işler ise, insana yönelik amaçlar taşır ve insanlar üzerinde herhangi bir etki işlevini yerine getirir. Beyaz yakalı işler, diğer insanlar üzerinde etkiyi gerektirmektedir ve buradaki işlev, insan davranışlarını organize etmek ve biçimlendirmektir. Bu bağlamda Girod'a göre beyaz yakalılar, insana yönelik amacı olan ve insan davranışlarını yönlendirme işlevini yerine getiren işlerlerde çalışanlardır (Girod'tan aktaran Bain ve Price, 1972:336).

Girod'un yaklaşımı öncelikle birçok mesleğin, bu kategorilerin birine veya diğerine net biçimde yerleştirilemediği gerekçesiyle eleştirilmektedir (Bain ve Price, 1972:336). Buna göre, nesneye yönelik amacı olan faaliyetlerle insana yönelik amacı olan faaliyetler arasındaki hattın bulanık olduğu çok sayıda durum vardır. Örneğin gazete ya da kitap basılması, hem nesneye, hem de insana yönelik bir iştir. Gazete ya da kitap basılması sürecinin bir bölümü nesneye yönelik bedensel bir iştir, çünkü kol gücü gerektiren nesneye yönelik amaç taşımaktadır. Gazete ya da kitabın bilgilendirici niteliği ise, insana yönelik bir amaç taşımaktadır. Burada bir taraftan kullanılabilir bir ürün olan nesne yaratılır, ama diğer taraftan aynı nesne, insan davranışlarını şekillendiren bir üründür. İkinci olarak, söz konusu ayrımın mesleki bölünme açısından daha sıkıntılı olduğu ifade edilmiştir. Örneğin bu ayrım üzerinden hareketle tipik bir beyaz yakalı meslek olan mühendislik, nesneye yönelik amacı olan bedensel bir faaliyet içerdiğinden mavi yakalı meslek olarak kabul edilebilir. Ya da genellikle kol gücüyle çalışan bir otobüs şoförünün, insana yönelik amaçla hareket ettiği için beyaz yakalı olarak kabul edilebileceği belirtilmiștir (Bain ve Price, 1972:336-337).

Bunların yanında, Girod'un çalışma ortamı ile ilgili olarak belirttiği beyaz yakalıların mühendisler, laborantlar gibi bazı istisnalar dişında, genellikle "bürokratik" çevrede çalışmasının, onları kol gücüyle çalışan işçilerden ayıran çevresel kriter olduğu bir ölçüde kabul edilebilir. Ancak, beyaz yakalıların çalıştıkları yerlerin "burjuvaya özgü" nitelik taşıdığı söylenemez. Örneğin, öteden beri beyaz yakalılar içerisinde say1lan büro işçilerinin çalışma ortamlarının burjuvaya özgü olduğunu iddia etmek mümkün değildir. Sadece bugün için değil, Girod'un görüşlerini dile getirdiği 1960'lardaki büro işçilerinin çalışma ortamlarının da burjuvaya özgü olduğu söylenemez. O dönemdeki büro işçilerinin, işlerin parçalanıp rutin hale getirilerek vasıfsızlaştırılması ve işçilerin yaratıcı güçlerini kullanmalarına fırsat veren özerkliklerinin ellerinden alınarak yetkilerinin az sayıdaki üst düzey yöneticiye aktarılması sonucunda, çalışma koşullarının neredeyse mavi yakalılar kadar kötü hale geldiğine ilişkin bulgular vardır (Braverman, 2008:296-302). Girod'un, 1950'lerden 1970'lere kadar yaygin olarak kabul edilen ve beyaz yakalıları ağırlıklı olarak orta s1nıfla özdeş gören Mills'in (1951) anlayışının fazlasıyla etkisinde kaldığını, dolayısıyla beyaz yakalıları daha çok sermayeye yakın gördüğünü belirtmek gerekir.

\section{Eleştirel Yaklaşım}

Yukarıdaki yaklaşımlar, çalışanları beyaz ve mavi yakalılar olarak ayırıp tanımlama girişiminde bulunmuşlardır. Bu girişimler sonucunda beyaz yakalıların, tutarlı teorik temele oturan bir tanımının yapıldığını söylemek mümkün değildir. Ayrıca, söz konusu yaklaşımların kriterleri üzerinden meslekler değerlendirildiğinde, birçok mesleğin hangi gruba dâhil olduğuna dair net bir fikir ortaya çıkmamaktadır. Bununla birlikte söz konusu yaklaşımların, beyaz ve mavi yakalılar arasında ayrım yapılması yönünde, günümüzde de varlığını sürdüren popüler bir anlayışın oluşmasına ve yerleşmesine hizmet ettiği inkâr edilemez. Eleştirel bakışla beyaz ve mavi yakalı ayrımına yaklaşan $G$. Sayers Bain ve Robert Price, bu popüler ayrımın temelinde hangi kriterin olduğu sorusuna cevap aramışlardır. Onlar, beyaz ve mavi yakalıları tanımlamaya yönelik kap- 
samlı açıklamalardan ziyade, tanım problemine dikkat çekmişlerdir. Yukarıda bahsedilen teorik yaklaşımları, beyaz yakalıların tanımlanmasındaki belirsizliği çözmek konusunda yetersiz kaldıkları gerekçesi ile eleştirmişlerdir (Hyman ve Price, 1983:14). Bain ve Price, özellikle teorik yaklaşımlarda esas alınan kriterlerin, beyaz ve mavi yakalılar arasında net bir ayrım yapılmasını sağlayamadığını belirtmişlerdir (1972:337).

Bain ve Price'a göre, beyaz yakalıların kim olduğuna ilişkin popüler kavrayışı belirleyen ana faktör, otoriteye yakınlik ya da otorite sahipliğidir. Çünkü otoriteye yakın ya da otoriteye sahip olmak, diğer yaklaşımların beyaz yakalılara ilişkin temel ayrımlar olarak önerdikleri giyim tarzı, iş çevresinin yapısı, yerine getirilen fonksiyon gibi çeşitli dişsal faktör ve simgelerden farkli olarak onları mavi yakalılardan ayıran daha temel bir özelliktir. Onlar, beyaz yakalı işlerin kol gücüne dayanmayan yapısını kabul etmektedir. Ancak bunun yanında, beyaz yakalıların yerine getirdiği görevlerin içeriğinin, otoriteye fonksiyonel bir yakınlık sağladığını belirtmektedirler. Onlara göre, söz konusu yakınlığın varlığına, gerçekte böyle bir yakınlık olmadığ 1 durumlarda bile inanılmaktadır. Çünkü iş çevresinin yapısı ve elbisenin türü gibi faktörlerin, otoriteye çevresel bir yakınlık yarattığına dair güçlü bir inanç mevcuttur. Diğer bir deyişle beyaz yakalıların çoğunun, mavi yakalılardan farksız olmalarına rağmen, giyim tarzı, çalışılan ortam gibi kolayca tanınabilen sembolik farklılıklara sahip olmaları, onların otoritenin kararları aldığ 1 ve yerine getirdiği yerlere yakın olduğuna ilişkin yaygın anlayışı beraberinde getirmektedir. Onlara göre bütün sektörlerde belirtilen yaygın anlayışın izlerini görmek mümkündür. Örneğin ticaret ve ulusal veya yerel yönetimlerde beyaz yakalılar, otoriteyle doğrudan ilişkisi olan, bir şekilde otoriteyle ilişkili olan masanın diğer tarafında bulunan çalışanlar olarak değerlendirilmektedir (1972:337-338).

Bain ve Price'a göre, beyaz yakalıların otoriteyle olan ilişkileri esasında sembolik bir ilişki niteliği taşımaktadır. Bu ilişki aracılığıyla otorite ile benzer ya da yakın oldukları düşünülmektedir. Onlara göre, burada "ilişki aracılığıyla benzer hale gelmek" olarak adlandırılabilecek bir süreç söz konusudur. Örneğin beyaz yakalılık gibi bir sembol, aslında otoriteyle ilişkili olunduğuna dair bir işarettir ve otoriteyle ilişkileri aracılığıyla beyaz yakalı gruplar, otorite ile eşdeğer hale getirilmektedir. Bu sembolik ilişki aracılığıyla beyaz yakalılar kendilerini otorite ile özdeşleştirdiği gibi, başkaları da onları otorite ile özdeş görmektedir (1972:338).

Bain ve Price, sosyal ve endüstriyel değişikliklerin beyaz yakalıları, üzerlerine yapıştırılan ve memnun oldukları sembollerden mahrum bıraktığını ve gerçekte onların hem fonksiyonel, hem de çevresel olarak otoriteye yakın olmadıklarını gösterdiğini belirtmektedir. Yani aslında otoriteye yakın ya da otoriteyle özdeş oldukları dönem çoktan sona ermiş ve sadece küçük bir azınlık için bunun gerçek olduğu görülmüştür. Bununla birlikte, otoriteye yakın ya da otoriteyle özdeş olduklarını çağrıştıran sembollere olan bakış değişmemiştir. Otoriteye yakınlığ 1 sembolize eden işaretlere sahip olan işler hala yaygin olarak beyaz yakalı işler olarak sinıflandırılmaktadır. Başka bir ifadeyle beyaz ve mavi yakalı ayrımının üzerine $\mathrm{ku}-$ rulduğu özellikler ortadan kalkmasına rağmen, beyaz yakalıların otoriteyle olan ilişkileriyle ilgili kanı ve buna bağlı olarak ayrımın kendisi halen devam etmektedir. Bain ve Price bu durumu, "kültürel geri kalmişlık" olarak nitelendirmektedir. Onlara göre bu kültürel geri kalmışlık, işlerin halen modası geçmiş sembolik kriterler aracılığıyla değerlendirilmesine yol açmaktadır (1972:338).

Richard Hyman'a göre, Bain ve Price'ın beyaz yakalılara ilişkin tartışmalara en önemli katkısı, otoriteye yakınlığın ya da otorite sahipliğinin beyaz yakalıların tanımlanmasına temel teşkil ettiğini ve otorite ile belirtilen türden ilişkilerin uzun süre önce ortadan kalkması nedeniyle büyük oranda 
sembolik kaldığını tespit etmeleridir (Hyman ve Price, 1983:14). Bahsedilen ilişkinin sembolik olduğu tespiti, beyaz yakalılar açısından açıklayıcıdır. Bugün gerçekten birçok beyaz yakalının otoriteyle olan ilişkisi semboliktir. Çünkü bu ilişki, otoriteye ait fonksiyonları üstlenmekten kaynaklanmamakta, sadece otoriteyle olan görünürdeki ilişkileri içermektedir. Örneğin bir firmanın satış temsilcisi, ona otoriteye yakınlık ya da otorite sahipliği sağlayacak kontrol ve denetim gücü gibi doğrudan kapitaliste ait bir fonksiyonu üstlenmemektedir, ancak otoritenin doğrudan temsilcisi olan üst düzey yönetici ya da birim yöneticileri ile toplantılarda, yemeklerde veya çeşitli şekillerde gün içerisinde iletişim kurarak görünürde bir ilişki içerisindedir. Burada otoriteye yakınlık ya da otorite sahipliği fiili olarak bulunmamakta, sadece görünürde sembolik bir ilişki olarak kalmaktadır. Aynı şekilde bir bankadaki pazarlama yetkilisi, mesai saatleri içerisinde ya da dışında çeşitli derecelerdeki yöneticilerle iletişim kurması nedeniyle otoriteyle ilişki içerisindedir, ancak neredeyse hiçbir konuda özerk karar alma yetkisi bulunmadığından bu ilişki sadece sembolik kalmaktadır.

Bain ve Price, yukarıda kısaca açıklanan yaklaşımları bağlamında beyaz yakalıları şu şekilde sınıflandırmaktadır: (1) Üst düzey yöneticiler ve idareciler; (2) üst düzey profesyoneller ya da uzmanlar; (3) alt düzey profesyoneller ya da uzmanlar ve teknisyenler; (4) formenler ve denetçiler; (5) büro işçileri; (6) satış temsilcileri ve tezgahtarlar (1976:346).

Beyaz yakalılara, bu genel sinıflandırmadan hareketle mesleki ayrımlar esas alınarak daha detaylı bakıldığında, son derece heterojen bir yapı ortaya çıkmaktadır. Buna göre beyaz yakalı meslekler şu alt gruplara ayrılarak sayılmıştır:

(1) İdari ve idareye yardımo işlerle ilgili meslekler: Bunlar muhasebeciler, hesap memurları, finans/sigorta/vergi işlerini yerine getiren uzmanlar, insan kaynakları yöneticileri ve yetkilileri (yönetici yardımcıları anla- mında), bilgi işlem çalışanları, satış ve pazarlama yönetici ve yetkilileri, reklam yönetici ve yetkilileri, hükümetle ilişkileri yürüten yönetici ve yetkililer, kamudaki yönetici, yetkili ve denetçiler, genel ve yerel yönetimlerdeki idarecilerdir.

(2) Sağlik, refah ve eğitim ile ilgili meslekler: Bu grup hekimler, pratisyen hekimler, hemşireler, ebeler, akademisyenler, öğretmenler, çeşitli eğitmenler ve sosyal görevlilerden oluşmaktadır.

(3) Fen, mühendislik, teknoloji ve benzer alanlarla ilgili meslekler: Bilim insanları, mühendisler, teknisyenler, mimarlar, tasarımc1lar, çeşitli araştırmacı ve planlamacılardır.

(4) Yönetimle ilgili meslekler: Üretim, ulaşım, depolama, ticaret alanlarındaki her türlü yönetim ve denetim işlerini yerine getiren yönetici, yetkili ve denetçiler. Örneğin büro, otel, süpermarket, üretim yöneticileri ve denetçileri, sekreterler, departman yetkililerinin hepsi bu gruptadır.

(5) Büro işleri ile ilgili meslekler: Büro müdürleri, şefleri, müfettişler; muhasebe, finans, sigortacılık, üretim ve ürün kontrolü, seyahat, iletişim, kütüphanecilik, kayıt alanlarındaki büro işleri ile diğer rutin büro işlerine ilişkin tüm meslekler bu gruptadır.

(6) Bu sayılan temel alanların dişında, gazeteciler, satış ve pazarlama alanındaki uzmanlar ve yardımcıları ile güvenlik ve koruyucu hizmetlerin büroya ilişkin işlerini yürüten tüm çalışanlar beyaz yakalı olarak kabul edilmektedir (Hyman ve Price, 1983:11-13).

\section{Tanım Sorununa Çözüm Arayışı}

Bahsedilen yaklaşımları bir tarafa koyarak "beyaz yakalılar" teriminin kullanımina bakıldığında temelde iki temel özellik üzerinden kavrandığ $\breve{1}_{1}$ görülmektedir. Bunlardan ilki beyaz yakalıların yürüttükleri işlerin fiziksel çabaya/kol gücüne dayanmaması ya da zihinsel çabaya/kafa gücüne dayanması, ikincisi ise görece eğitimli olmalarıdır (Giddens, 2005:55; Edgell, 1998:72; Sobel, 1989:15; Jenkins ve Sherman, 1979:13; Mills, 1951:64- 
65). Türkiye'de doğrudan beyaz yakalılara ilişkin yapılan az sayıdaki çalışmada da beyaz yakalıların, aynı iki temel özellik üzerinden kavrand $1 \breve{g}_{1}$ görülmektedir (Bora ve diğ., 2011:7/18-19; Öztürk, 2011:17; Bora, 2010:48).

Türkiye'de beyaz yakalılara ilişkin yapılan tek tanımı, Türkiye Sendikacılık Ansiklopedisi'nde görmek mümkündür. Burada beyaz yakalılar "çalışmalarında kafa emeği (düşünsel çalışma) kol emeğine (bedensel çalışma) ağır basan ücretliler" olarak tanımlanmıştır. Bu terimin, kafa gücüyle çalışanları, bedensel emekleri ağır basan geleneksel mavi yakalılardan ayırmak için kullanıldığ 1 ifade edilmiştir. Bu tanım çerçevesinde beyaz yakalıların idari işlerde, gelişmiş teknoloji kullanan modern sanayide, özellikle optik, elektronik, kimya ve ilaç sanayinde, teknik ve bilim alanlarında çalışanlar ve hizmet sektöründe çalışanların bir kısmından oluştuğu belirtilmiştir. Beyaz yakalılara örnek olarak sanayideki teknisyenler, vasıflı uzman işçiler, laborantlar, büro çalışanları, eğitim ve öğretim elemanları, mühendisler, teknik elemanlar, banka, sigortacilık, ticaret gibi alanlardaki emekçiler sayılmıştır. Beyaz yakalıların en önemli ortak özelliği olarak, görece yüksek bir eğitim ve uzmanlaşma düzeyine sahip olmaları ile düşünsel çalışmalarının bedensel güç ve çalışmaya ağır basması gösterilmiştir (Tarih Vakfı, 1996:164). Bu tanimlamada beyaz yakalilar "ücretliler" olarak kabul edilmiştir. Dolay1sıyla serbest çalışan beyaz yakalılar ya da bağımsız profesyoneller olan avukatlar, çeşitli danışmanlar, muhasebeciler gibi çalışanlar tanımın dışında bırakılmıştır.

Beyaz yakalılar konusunda anlatılanlar çerçevesinde ilk olarak, beyaz ve mavi yakalıların, zihinsel/fiziksel ya da kafa/kol gücüne dayalı çaba ayrımı üzerinden tanımlandığ1 yaygın olarak kabul edilmektedir. İkinci olarak, her ne kadar birçok beyaz yakalının yürüttüğü işler niteliksizleşse de, beyaz yakalıların görece eğitimli oldukları tartışma götürmez. Bunun en önemli nedeni beyaz yakalıların, yürüttükleri işlerin niteli- ğine bakılmaksızın, eğitimli olmaları önkoşulu ile işe alınmasıdır.

Beyaz yakalılar değerlendirilirken sayılan özelliklere ek olarak yönetimle ya da otoriteyle olan ilişkilerine gönderme yapılması anlamlı görünmektedir. Çünkü beyaz yakalıların otoriteyle olan ilişkisi, bugün genellikle sembolik bir nitelik taşısa bile, diğer çalışanlara göre önemli bir farklılık yaratmaktadır. Bu bağlamda beyaz yakalıların kim olduğu belirlenirken eleştirel yaklaşım tarafından dile getirilen "otoriteye yakınlık ya da otorite sahipliği" ölçütünün dikkate alınması gerekmektedir. Esasında söz konusu ölçütün sübjektif nitelik taşıdığı ve yakınlığın ya da sahipliğin ölçüsünün ne olduğuna dair net kriterler bulunmadığ 1 söylenebilir. Bundan daha önemlisi otoriteye yakınlık ya da otorite sahipliği beyaz yakalıların bir bölümü için gerçekten varken, büyük bir çoğunluğu için fiili olarak ortadan kalkmıştır. Bugün böyle bir sahiplik ya da yakınlık büyük oranda "sembolik" olarak varlığını sürdürmektedir. Tüm bunlara rağmen, beyaz yakalıların otoriteye yakın ya da otorite sahibi olması onları diğer çalışanlardan ayırması bakımından halen büyük önem taşımaktadır. Çünkü beyaz yakalıların yürüttükleri işler şimdi ya da tarihsel olarak mutlaka otorite ile bahsedilen türden bir ilişkiyi içermektedir. Bugün böyle bir ilişkinin fiili olarak bulunmadığ işlerde bile, tarihsel miras nedeniyle söz konusu ilişkinin izlerini bulmak mümkündür. Otoriteye yakınlık ya da otorite sahipliğinin halen sembolik olarak varlığını sürmesi bunun bir kanıtıdır.

Beyaz yakalıların otorite ile olan ilişkilerinin arka planında, fonksiyonel yaklaşımın tarif ettiği sermaye birikiminin genişlemesine paralel olarak, bizzat kapitalist tarafından yerine getirilen sermayeye ait fonksiyonların ücretli çalışanlara zorunlu olarak aktarılmasının bulunduğu gözden kaçırılmamalıdır. Bu önemlidir, çünkü beyaz yakalıların büyük bölümünün uzun süre sermayeye özgü işleri yürütmesi, onların belli oranda otoriteye yakın ya da otorite sahibi olduklarına ilişkin anlayışın pekişme- 
sini sağlamıştır. Söz konusu anlayış öylesine güçlüdür ki bugün beyaz yakalılar, otoriteye yakın ya da otorite sahibi olma niteliklerini ve bu niteliğin onlara sağladığ 1 avantajları büyük oranda kaybetmelerine rağmen, sembolik olarak halen varlığını sürdürmekte ve beyaz yakalıların yürüttüğü işler açısından halen belirleyici görünmektedir.

Bu bağlamda beyaz yakalılar, fiziksel çabaya/kol gücüne baskın bir biçimde zihinsel çabaya/kafa gücüne dayalı olarak işlerini yürüten; genellikle sembolik olmakla birlikte, belli oranda otoriteye yakın ya da otorite sahibi olan; görece eğitimli çalışanlar şeklinde tanımlanabilir. Beyaz yakalılar genel olarak iki ana gruba ayrılabilir. Bunlar teknik ve teknik olmayan işleri yerine getiren beyaz yakalılardır. Teknik beyaz yakalılar, teknik uzmanlık gerektiren işleri yürüten mühendis, mimar, teknisyen, tasarımc1, şehir plancısı, laborant gibi çalışanları kapsamaktadır. Teknik olmayan beyaz yakalılar ise rutin büro işleri ile yönetim (yönetimin bir parçası olarak denetim, kontrol, koordinasyon), finans, eğitim, sağlık, pazarlama, reklam, ticaret, basın-yayın, hukuk gibi alanlardaki işleri yürüten çalışanlardır. Teknik olmayan beyaz yakalılar rutin büro işçilerini; çeşitli kademelerdeki yönetici, yetkili ve denetçileri; muhasebeci, bilgi-işlemci, danışman gibi çeşitli uzmanları; öğretmen, akademisyen, doktor, hemşire, banka çalışanı, satış temsilcisi, reklamc1, gazeteci, avukat gibi çalışanları kapsamaktadır.

\section{Sonuç}

Ücretli emek içerisindeki en önemli çal1şan gruplarından birisi haline gelen ve 21 . yüzyılda öneminin artması muhtemel görünen beyaz yakalıların net bir tanımının yapılması güçtür. Bu güçlüğün en önemli nedeni, beyaz yakalıların yürüttükleri işlerin heterojen bir yapıya sahip olmasıdır. Söz konusu heterojenlik, beyaz yakalı işlerin doğasının ortaya konulmasını ve bu işlere ilişkin genel açılamalar yapılmasını zorlaştırarak beyaz yakalıların tanımlamasinı bir sorun haline getirmektedir. Bütün zorluğuna rağmen, beyaz yakalıları diğer çalışanlardan ayırt etmeye yarayan belli ortak ölçütlere ulaşılarak beyaz yakalıların kim olduğu konusundaki muğlâklığın bir ölçüde giderilmesi mümkündür.

Yukarıda ortaya konulan yaklaşımlar, her ne kadar başka sorunları beraberinde getirse de beyaz yakalıların tanımlanması meselesine tartışmasız ışık tutmaktadır. Bu bağlamda öncelikle zihin-kas yaklaşımı, beyaz yakalıların tanımlanması ve beyaz yakalılara ilişkin yaygın anlayışı șekillendirmesi bağlamında baskın bir biçimde etkisini sürdürmektedir. Zihin-kas yaklaşımının açtı ̆̆ yoldan hareketle beyaz yakalıların $\mathrm{kol} / \mathrm{kas}$ gücüyle çalışanların dıșında kalan çalıșanlar oldukları ya da bütünüyle kafa/zihin gücüyle çalıştıkları iddia edilemese bile, $\mathrm{kol} / \mathrm{kas}$ gücüne baskın bir biçimde, kafa/zihin gücü ile çalıştıkları söylenebilir. Bu temel ölçüt, zihin-kas yaklaşımının beyaz yakalıların tanımlanması konusuna en önemli katkısıdır.

Beyaz yakalıların tanımlanması konusundaki ikinci ölçüt eğitimdir. Beyaz yakal1lar konusundaki tüm tartışmalar ve çalışırken baskın olarak zihinsel etkinlikte bulunmaları göz önüne alındığında, görece eğitimli oldukları kolaylıkla söylenebilir. Eğitim konusunda önemli bir nokta vurgulanmalıdır. Özellikle rutin büro işlerini yürüten beyaz yakalıların, üstlendikleri işlerin parçalanıp rutin hale getirilerek niteliksizleştirilmesi, onların eğitimli olmadıkları anlamına gelmemektedir. Başka bir deyişle yürüttükleri işlerin yüksek nitelik ya da eğitim gerektirmemesi, beyaz yakalıların görece eğitimli oldukları gerçeğini değiştirmemektedir. Çünkü beyaz yakalıların yürüttükleri işler niteliksiz olsa bile, beyaz yakalı işlere girişin önkoşulu yine görece eğitimli olmaktır.

Üçüncü ölçüt, eleştirel yaklaşım tarafından ileri sürülen ve günümüzde genellikle sembolik nitelik taşıyan otoriteye yakınlık ya da otorite sahipliğidir. Beyaz yakalıların yürüttüğü işler onlara, ya bugün halen var olan ya da tarihsel olarak var olan otoriteye ya- 
kınlık ya da otorite sahipliğgi sağlamıştır. Bu otorite ilişkisi, beyaz yakalı emeğin doğuşundan beri vardır ve bugün sembolik bile olsa halen varlığını sürdürmektedir. Dolay1sıyla otoriteyle olan bu tür bir ilişkinin, ister gerçekten isterse sembolik olsun, beyaz yakalıları diğer çalışanlardan ayırmak konusunda anlamlı bir ölçüt olduğu söylenebilir.

Fonksiyonel yaklaşımın katkısı ise, beyaz yakalıların otoriteyle olan ilişkisinin arka planını açıklamasıdır. Kapitalist üretim süreçlerinin karmaşıklaşması sonucu parçalanarak beyaz yakalılara aktarilan fonksiyonların esasen kapitaliste ait fonksiyonlar olmasi, beyaz yakalıların otoriteye yakın ya da otorite sahibi olmalarını sağlamiştır. Bu durum, bugün büyük oranda ortadan kalkmıştır. Ancak beyaz yakalıların tarihsel olarak kapitaliste ait fonksiyonları üstlenmesi anlamında devraldığı miras, halen otorite ile belirtilen türden ilişkinin görünürde sürmesine neden olmaktadır. Fonksiyonel yaklaşım tarafından tarif edilen bu süreç, otorite ile olan ilişkinin, özellikle de söz konusu ilişkinin bugün niçin büyük oranda sembolik olduğunun arka planını açıklamaktadır.

Son olarak beyaz yakalılar konusunda iki önemli noktanın vurgulanmasinda fayda vardır. İlki, beyaz ve mavi yakalı ayrımı, teorik tartışmalarda veya günlük dilde çoğunlukla başvurulan bir ayrım olmakla birlikte, tüm çalışanların mutlaka beyaz ve mavi yakalı kategorilerinden birisine dâhil edilmesi gibi bir zorunluluk bulunmamaktadır. Diğer bir deyişle tüm çalışanlar, beyaz ve mavi yakalı gibi iki gruba ayrılmış değildir. İkinci olarak, beyaz ve mavi yakalı ayrımından, birbirinin karşıtı iki grubun anlaşılmaması gerektiği özellikle belirtilmelidir. Bu iki çalışan grubu, sınıfsal anlamda iki ayrı kutbu değil, bir bütünün parçalarını oluşturmaktadır. Daha açık bir ifadeyle her iki gruptaki çalışanlar da işçidir. Çünkü onları birbirinden ayıran nitelikler, işçi olup olmamaları bağlamında önem taşımamaktadır.

\section{Kaynakça}

Bain, George Sayers ve Robert Price (1976), “Union Growth Revisited: 1948-1974 In Perspective", British Journal of Industrial Relations, Vol: 14, No. 3, ss. 339356, Ebsco-Host Veritabanı (21 Kasım 2009).

Bain, George Sayers ve Robert Price (1972), "Who Is A White-Collar Employee", British Journal Of Industrial Relations, Vol: 10, No: 3, ss. 325-339, Ebsco-Host Veritabanı (21 Kasım 2009).

Bora, Tanıl, Aksu Bora, Nemci Erdoğan, İlknur Üstün (2011), Boşuna mı Okuduk? Türkiye'de Beyaz Yakalı İşsizliği, İstanbul: İletişim Yayınları.

Bora, Tanıl (2010), "Mavileşen Beyaz Yakalılar", Birikim, Sayı: 259, ss. 48-64.

Braverman, Harry (2008), Emek ve Tekelci Sermaye, Yirminci Yüzyılda Çalışmanın Değersizleştirilmesi, Çiğdem Çidamlı (çev.), İstanbul: Kalkedon Yayınları.

Callinicos, Alex ve Chris Harman (2006), Neo-Liberalizm ve Sinif, Osman Akınhay (çev.), İstanbul: Salyangoz Yayınları.

Edgell, Stephen (1998), Sınıf, Didem Özyiğit (çev.), Ankara: Dost Kitabevi.

Erdayı, A. Utku (2012), “Beyaz Yakalı İşçilerde Örgütlenme: Türk Bankacılık Sektöründe Bir Alan Araştırması", Yayınlanmamış Doktora Tezi, Marmara Üniversitesi Sosyal Bilimler Enstitüsü.

Giddens, Anthony (2005), Sosyoloji Kisa ve Fakat Eleştirel Bir Giriş, Ülgen Yıldız Battal (çev.), Ankara: Phoenix Yayınevi.

Hyman, Richard ve Robert Price (1983), The New Working Class? White-Collar Workers And Their Organizations, London: Macmillan Pres. 
Jenkins, Clive ve Barrie Sherman (1979), White-Collar Unionism: The Rebellious Salariat, Boston: Routledge \& Kegan Paul.

Mills, C. Wright (1951), White Collar: The American Middle Classes, New York: Oxford University Pres.

Öztürk, Yunus (2011), “Biz Beyaz Yakalılar Eyleme Hazırız", Mesele, Sayı: 55, ss. 16-20.

Sobel, Richard (1989), The White Collar Working Class: From Structure To Politics, New York: Praeger Publishers.

Sohn-Rethel, Alfred (2011), Zihin Emeği Kol Emeği, Epistemoloji Eleştirisi, İstanbul: Metis Yayınları.

Tarih Vakfı (1996), Türkiye Sendikacılık Ansiklopedisi. Cilt: 1, İstanbul: Türkiye Ekonomik ve Toplumsal Tarih Vakfı.

TÜİK (2011), “İstihdam Edilenlerin Meslek Grubu", İşgücü İstatistikleri, http://www.tuik.gov.tr (11 Ocak 2011). 